\title{
CAPACITY BUILDING MELALUI BIMBINGAN PENGEMBANGAN PERPUSTAKAAN DESA
}

\author{
Iskandar1, Amin Saleh² \\ Prodi DIII Perpustakaan, Universitas Muhammadiyah Mataram \\ 2Prodi DIII Perpustakaan, Universitas Muhammadiyah Mataram \\ iskandarngali94@gmail.com
}

INFO ARTIKEL

\section{Riwayat Artikel:}

Diterima: 27-02-2020

Disetujui: 08-03-2020

\section{Kata Kunci:}

1. Pembimbingan

2. Pengembangan

3. peer learning meeting

4. Perpustakaan Desa

\section{ABSTRAK}

Perpustakaan Nasional melalui program trasformasi perpustakaan berbasis inklusi sosial siap mewujudkan keberadaan perpustakaan sampai ke setiap desa melalui pembimbingan pengembangan perpustakaan desa dengan cara pendampingan dan penerapan program di perpustakaan desa.

Perpustakaan desa menjadi bagian dari sistem sosial yang berperan untuk mengembangkan karakter, kompetensi dan literasi masyarakat yang dapat dijadikan sebagai daya saing masyarakat pedesaan untuk mengimbangi terjadinya percepatan program pembangunan pemerintah pusat

Program perpustakaan desa di dukung oleh Perpustakaan Nasional, Perpustakaan Provinsi, Perpustakaan Kabupaten sebagai strategi perpustakaan untuk mewujudkan pelayanan tanpa membedakan status, pekerjaan, ekonomi, jabatan, pendidikan dan sosial budaya sehingga perpustakaan tersedia untuk menjadi kebutuhan setiap masyarakat sepanjang hayat yang terdekat.

\section{A. PENDAhuluan}

Perpustakaan dengan tujuan utamanya yaitu memberikan pelayanan informasi guna menunjang kebeutuhan masyarakat atau yang di sebut dengan istilah pemustaka menurut Undang-Undang tentang perpustakaan No. 43 tahun 2007. Dalam memperhatikan persebaran pemustakaan yang sulit di jangkau jika hanya mengandalkan perpustakaan Nasional, Provinsi dan Kabupaten/Kota, maka Perpustakaan Nasional mengambil langkah untuk menjalankan Program Trasformasi Perpustakaan Berbasis Iklusi Sosial yang di laksanakan mulai Agustus 2018 sampai dengan saat ini. Program ini sebelumnya di kembangkan oleh Bill \& Melinda Gates Foundation tahun 2011 s/d 2018 dari perjalanan panjangnya program ini fokus untuk mengembangkan perpustakaan sehingga dari perjalan tersebut perpustakaan Nasional memandang program ini bagus untuk dilanjutkan sebagai upaya nyata dalam mendorong peningkatan literasi pemustaka dengan melakukan penguatan fungsi perpustakaan umum di tingkat provinsi, kabupaten dan sampai ke desa.

Perpustakaan desa/kelurahan dibentuk atas dasar undang-undang No 43 tahun 2007 tentang perpustakaan dan Standar Nasional Perpustakaan yang di terbitkan oleh Perpustakaan Nasional Repoblik Indonesia sebagai wujud dari kepedulian pemerintah dalam mendukung pembangunan yang bersipat menyeluruh.

Hadirnya perpustakaan desa di targetkan menjadi solusi bagi kebuntuan pendidikan sepanjang hayat yang memperhatian jaminan negara terhadap hak pendidikan masyarakat dari segi nonformal 


\section{B. LANDASAN TEORI}

Keberadaan perpustakaan pada tatanan masyarakat menjadi hal yang fital sesuai dengan pendapat sutarno NS 2004 yang menyatakan bahwa perpustakaan akan memiliki nilai guna maksimal apabila perpustakan di bangun oleh masyarakat.

Secara pendekatan sosiologis istilah institusi dan sistem perpustakaan dapat dikatakan sebagai sebuah institusi sosila jika memiliki struktur yang telah bertahan sepanjang waktu tertentu di dalam wilayah tertentu. Sedangkan sebagai sebuah sistem sosial, perpustakaan adalah intraksi antar anggota masyarakat yang di produksi dan direproduksi secara terus menerus sehingga terpola dan terlihat sebagai kegiatan rutin. Dalam intraksi ini, anggota-anggota masyarakat memanfaatkan tata-aturan dan sumber daya yang berupa struktur sosial yang tumbuh di masyarakat (perpustakaan nasional RI, 2007)

Dengan demikian perpustakan adalah sistem sosial yang terdapat di dalamnya intraksi antara berbagai pihak dan berlangsung terus-menerus. Sementara dalam kegiatan ini diperlukan kegiatan komuniasi, kekuasaan dan wewenang yang menekankan pada pemberlakuan sangsi-sangsisosial.

Selanjutnya perpustakaan desa memerlukan aturan-aturan yang dapat dipahami bersama dalam pemanfaatannya untuk menjadi jawaban kebutuhan masyarakat sehingga terwujud perpustakaan sebagai satu sistem umum. Selanjutnya Cara masyarakat desa menetapkan serta menerapkan norma-norma tentang perpustakaan inilah yang menentukan seberapa tertanamnya struktur legitimasi perpustakaan di kalangan msayarakat desa. Sejalan dengan itu, diperlukan alokasi fasilitas yang memungkinkan pihak-pihak yang menggunakan perpustakaan mencapai tujuan-tujuannya. Legitimasi dan dominasi ini bersama-sama dengan tata-cara pemanfaatan perpustakaan untuk kegiatan komunikasi pengetahuan membentuk "struktur sosial perpustakaan desa".
Perpustakaan desa memiliki ranah kerja bidang jasa layanan informasi yang dimaksudkan untuk memenuhi kebtuhan informasi bagi setiap pemustaka yang menjadi ranah atau wilayah perpustakaan seperti perpustakaan desa.

Perpustakaan desa menurut standar nasional adalah Perpustakaan yang diselenggarakan oleh pemerintah desa/ kelurahan yang mempunyai tugas pokok melaksanakan pengembangan perpustakaan di wilayah desa/kelurahan serta melaksanakan layanan perpustakaan kepada masyarakat umum yang tidak membedakan usia, ras, agama, status sosial ekonomi dan gender.

Sementara pemerintah desa adalah pembagian wilayah administratif di Indonesia di bawah kecamatan, yang dipimpin oleh Kepala Desa yang terdiri dari kumpulan beberapa unit permukiman kecil yang disebut kampung (18-04-2020. https://id.wikipedia.org)

Adanya perkumpulan kampung-kampung yang di dalamnya terdiri dari berbagai lapisan masyarakat, suku dan budaya maka akan menuntut pemerintah desa sebagai pihak pelaksana administrasi desa untuk menjadi garda terdepan melayani kebutuhan masyarakat salah satunya adalah kebutuhan informasi.

Indonesia sebagai negara berkembang menganut perinsip menstimulasi masyarakat untuk lebih produktif sehingga pemerintah harus menyediakan perpustakaan sebagai sarana menyediakan informasi bagi masyarakat. Dengan demikian maka sudah menjadi tugas perpustakaan untuk melakukan pelayanan perpustakaan dan sekaligus pengembangan layanan perpustakaan

Pengembangan Perpustakaan bertugas dalam melaksanakan deposit, mengembangkan, dan mengelola bahan pustaka serta membina, memberdayakan kelembagaan dan sumber daya manusia perpustakaan. Berdassarkan fungsinya maka Pengembangan Perpustakaan menurut 
http://dpad.jogjaprov.go.id mempunyai fungsi sebagai berikut:

1. Penyusunan program kerja;

2. Penyiapan bahan kebijakan teknis di bidang deposit, pengembangan dan pengelolaan bahan pustaka;

3. Pembinaan dan pemberdayaan kelembagaan dan sumber daya manusia;

4. Pelaksanaan sosialisasi, pemantauan, penerimaan, dan pengelolaan karya cetak dan karya rekam;

5. Penyiapan bahan kebijakan teknis tentang karya cetak dan karya rekam;

6. Pelaksanaan kajian pengembangan perpustakaan dan minat baca;

7. Pembinaan profesi sumber daya manusia perpustakaan;

8. Pelaksanaan pemasyarakatan perpustakaan dan peningkatan minat baca;

9. Pelaksanaan dan pengembangan kerjasama perpustakaan;

10. Fasilitasi penyelenggaraan perpustakaan;

11. Pelaksanaan monitoring, evaluasi, dan penyusunan laporan program bidang pengembangan perpustakaan; dan

12. Pelaksanaan tugas lain yang diberikan oleh atasan sesuai dengan tugas fungsinya

Secara legalitas formal, perpustakaan desa mempunyai dasar hukum pelaksanaanya, yaitu Surat Keputusan Menteri Dalam Negeri dan Otonomi Daerah Nomor 3 Tahun 2001, tentang Perpustakaan Desa/Kelurahan (Menteri Dalam Negeri dan Otonomi Daerah, 2001). Secara definitif perpustakaan desa adalah "perpustakaan masyarakat” sebagai salah satu sarana/media untuk meningkatkan dan mendukung kegiatan pendidikan masyarakat pedesaan, yang merupakan bagian integral dari kegiatan pembangunan desa/kelurahan. Dari pengertian tersebut terdapat empat kata kunci tentang perpustakaan desa yaitu: (1) perpustakaan berbasis masyarakat, (2) berfungsi sebagai sarana dan media belajar, (3) untuk meningkatkan dan mendukung pendidikan masyarakat, dan (4) merupakan bagian integral pembangunan. Jika dilihat dari empat kata kunci tersebut pengertian hakiki dari perpustakaan desa adalah perpustakaan yang dikembangkan dan didirikan atas inisitif dan prakarsa dari pemerintah desa, penyelenggaraannya juga menjadi tanggung jawab pemerintah desa, yang digunakan masyarakat sebagai media untuk mendukung pendidikan informal di lingkungan masyarakat yang menjadi bagian yang tak terpisahkan dari program pembangunan dalam pelaksanaan pembangunan desa.

\section{BIMBINGAN PNGEMBANGAN PERPUSTAKAAN DESA}

1. Pendampingan

Mewujudkan fungsi perpustakaan desa secara umum adalah tanggung jawab bersama yang di emban oleh perpustakaan nasional, perpustakaan provinsi, perpustakaan kabupaten dan perpustakaan desa. Namun yang perlu di perhatikan adalah perpustakaan tidak bisa berdiri sendiri melainkan dengan bersinergi, di level masing-masing perpustakaan diharapkan mampu untuk bersinergi supaya tercipta kepedulian bersama karena akan sangat berpengaruh pada program perpustakaan

Dengan demikian perputakaan mentargetkan supaya apa yang menjadi bahan informasi dapat digunakan oleh masyarakat luas sehinga jalan untuk menyentuh masyarakat secara langsung adalah dengan mengoptimalkan pemerintah desa menjadi bagian dari pintu masuk masyarakat untuk mendapatkan layanan informasi dalam bentuk perpustakaan desa

Tugas dan fungsi perpustakaan desa yang dimaksudkan sebagai tempat atau sumber belajar masyarakat dilaksanakan secara terorganisir 
mulai dari penetapan surat keputusan kepala desa tentang pengelolaan perpustakaan yang meliputi penetapan sumber anggara, ruang atau gedung perpustakaan, koleksi perpustakaan, pengelolaan perpustakaan dan sumber daya manusia perpustakaan

Tata kelola perpustakaan secara terstruktur dan sistemaris akan terlaksana dengan maksimal apabila terjadi proses pendampingan yang berkesinambungan antara :

a. Perpustakaan Nasional

Pendampingan yang dilakukan oleh perpustakaan nasional dilakukan mulai dari pembuatan regulasi, pedoman atau standar perpustakaan, pasilitas dan pelatihan tenaga perpustakaan

b. Perpustakaan Provinsi

Kontribusi perpustakaan provinsi dalam mendukung tumbuh kembang perpustakaan desa dimulai dari pembuatan regulasi tingkat provinsi, pasilitas pendukung perpustakaan, bimbingan tekhnis dan evaluasi program perpustakaan

\section{c. Perpustakaan Kabupaten}

Bentuk pendampingan perpustakaan kabupaten dimulai dari pertama sosialisasi kepada pemerintah desa tentang pentingnya pengembangan perpustakaan desa secara professional untuk menjadi bagian dari pelayanan pemerintah kepada masyarakat dalam hal pengembangan sumber daya informasi masyarkat

Kedua, perpustakaan kabupaten mendorong kepala desa untuk menerbitkan surat keputusan tentang pengelolaan perpustakaan desa yang di dalamnya menyatakan tentang sekurang-kurangnnya menetapkan tiga (3) orang pelaksana tekhnis perpustakaan
Ketiga, perpustakaan kabupaten melakukan pendampingan dalam pengelolaan perpustakaan desa baik tekhnis maupun langkah-langkah strategis

Keempat perpustakaan kabupaten melakukan evaluasi sampai menyelenggarakan kompetisi program perpustakaan sebagai wujud untuk meningkatkan persaingan program antar perpustakaan desa biasanya perpustakaan kabupaten menyelenggarakan lomba perpustakaan desa

d. Pemerintah desa

Pelaksanaan pemerintahan desa dilaksanakan oleh pemerintah desa yang terdiri dari kepala desa sebagai pemegang pemerintahan tertinggi kemudian ditambah dengan perangkat desa.

Kemudian tugas kepala desa berikut dengan perangkat desa meliputi melaksanakan pemerintahan desa, melakukan pengembangan desa, pembinaan kemasyarakatan dan pemberdayaan masyarakat desa

Melihat tugas pemerintah desa sebagai ujung perjuangan pemerintah pusat yang bersentuhan langsung kepada masyarakat sangat menentukan keberhasilan dari semua program unggulan yang di targetkan dalam pembangunan diantaranya adalah mencerdaskan kehidupan bangsa. Jadi pembinaan dan pemberdayaan masyarakat sangat bergantung pada kualitas program pembangunan desa.

Pembinaan masyarakat disa meliputi pembinaan kegiatan pemuda dan olah raga, pembinaan organisasi perempuan/PKK, dan pembinaan kesenian dan sosial budaya. Dari tiga pengkatagorian jenis pembinaan yang di canangkan oleh pemerintah desa sangat di pengaruhi oleh karakter masyarakat, kemampuan/skill masyarakat, dan literasi 
yang sering dimaknai dengan keterbukaan wawasan. Literasi itu sendiri meliputi Literasi baca,Literasi budaya,Literasi teknologi, dan Literasi keuangan. Dengan demikian maka pemerintah desa secara tidak langsung memiliki peran penting dalam memperhatikan tumbuh dan kembang masyarakat sehingga bagian penting tersebut akan bida di penuhi dengan menyediakan referensi dan informasi yang mampu untuk meningkatkan kemampuan dan keahlian masyarakat.

Adapun cara untuk menjamin masyarakat dalam hal pengemabgan dari pemerintah pusat adalah dengan melaksanakan fungsi perpustakaan desa yang burtujuan untuk menjadi ruang belajar masyarakat tampa melihat status, ekonomi, pendidikan, kasta mapun jabatan. Semua masyarakat berhak menerima jasa layanan informasi yang disedikan oleh perpustakaan desa sehingga perpustakaan desa mampu menjawab tujuan pemerintah dalam hal menjamin pendidikan masyarakat jadi perpustakaan desa menjadi tempat pendidikan nonformal sepanjang hayat.

Kemudian strategi pengembangan perpustakan desa bisa dilakukan dengan tiga pendekatan :

1) Perpustakaan berorientasi pada kegiatan masyarakat. Maksudnya adalah segala informasi yang di adakan maupun dikembangkan oleh perpustakaan desa berlandaskan pada kebutuhan masyarakat dan selanjutnya perpustakaan juga melibatkan masyarakat dalam proses perpustakaan. Sehingga keberadaan perpustakaan benar-benar berjalan seirama dengan kebuthan masyarakat

2) Perpustakaan desa menyediakan layanan komputer dan menyediakan akses internet.

3) Perpustakaan desa guna mendukung setiap program yang telah di canangkan harus didukung oleh kegiatan advokasi yang di tujukan kepada pemangku kepentingan dan pendukung kegiatan seperti tokoh masyarakat mulai dari pemuda, agama, perempuan dan sosial budaya

\section{Monitoring dan evaluasi program}

a. Sosialisasi program

Sosialisasi program perpustakaan bertujuan untuk menubuhkan kesadaran dan dukungan masyarakat tentang pentingnya perpustakaan desa selain itu juga sosialisasi diperlukan untuk mendapat dukungan dari pengambil kebijakan seperti kepala desa dan stakeholder terkait seperti keterlibatan BPD, PKK, Karang taruna, dan perangkat desa lainnya supaya bersama-sama dengan aparat desa menyadari pentingnya pengembangan perpustakaan untuk mewujudkan kecerdasan masyarakat

b. Penyediaan komputer

Komputer dan internet di dalam perpustakaan menjadi bagian dari alat telusur yang wajib untuk dimiliki sehingga hadirnya komputer dan internet menjadi bagian dari penyediaan jasa layanan yang disediakan untuk memenuhi kebutuhan pengelola dan pemustaka untuk lebih mengefektifkan akses informasi yang cepat, tepat dan akurat sebagai bagian dari cara melengkapi isi informasi yang termuat dalam buku teks. Adapun unit atau jumlah komputer yang akan disediakan oleh perpustakaan desa idealnya berimbng dengan jumlah masyarakat namun tetap di sesuaikan dengan kemampuan desa itu sendiri.

c. Pelatihan

Untuk mewujudkan perpustakan desa yang refresentatif perlu untuk memberikan pelatihan terhadap pengelola perpustakaan desa dengan tujuan untuk meningkatkan pengetahuan dan keterampilan dalam melaksanakan tugas sebagai pengelola 
perpustakaan maupun sebagai tenaga yang bertugas pada bidang jasa layana informasi seperti dalam mengoprasikan komputer, pengadaan bahan pustaka, pengolahan bahan pustaka, perawatan bahan pustaka, dan promosi perpustakaan

d. Mentoring dan monitoring

Pengawssan menjadi bagian yang penting untuk diterapkan pada perpustakaan desa sebagai bentuk nyata dari pendampingan guna mendukung kemampuan pengelola perpustakaan desa khususnya dalam menyikapi setiap tugas dan fungsinya sebagai penyedia layanan jasa informasi. Selain itu mentoring juga bertujuan untuk memastikan kualitas penerapan program apakah seuai dengan standar yang telah ditetapkan atau masih perlu dilakukan penyesuaian menuju tercapainya tujuan ideal yang telah di tetapkan oleh pusat dalam hal ini perpustakaan nasional, perpustakaan provinsi, dan perpustakaan kabupaten.

e. Standar perpustakaan desa

Khadiran perpustakaan desa dalam pemerintahan desa saat ini masih dirasa sebagai program pelengkap atau mungkin program pendukung yang harus dikembangkan oleh pemerintah desa. Sejauh ini pemerintah desa msih berfokus pada program-program yang bersifat fisik seperti pembangunan jalan, pasar dan olah raga. Namun seiring dengan tumbuh dan kembangnya kesadaran pemerintah untuk melakukan pembinaan dan pengembangan kemampuan masyarakat supaya mampu bersaing tingkat lokal, nasional bahkan tingkat internaional sangat di pengaruhi oleh pengetahuan dalam hal ini kemampuan literasi dimana kemampuan ini akan banyak di bantu oleh adanya perpustakaan yang refresentatif.
Adapun standar utama pengelolaan perpustakaan desa menurut Theresia 2011 minimal terdiri dari tiga faktor utama yaitu:

1. Tempat/gedung

Kesediaan tempat/gedung menjadi kunci adanya perpustakaan sehingga mudah untuk menentukan akses. Jauh dan dekatnya tempat/gedung perpustakaan biasanya menjadi masalah tersendiri bagi pemustaka untuk turut serta memanfaatkan perpustakaan. Sehingga dengan pertimbangan inilah maka muncul perpustakaan desa yang menjadi perpanjangan tangan dari perpustakaan nasional untuk menyentuh lapisan masyarakat terbawah dalam hal menyediakan bahan informasi atau referensi. Dengan demikian maka peluang masyarakat untuk mendapatkan sumber yang relevan dengan kebutuhan sehari-hari sebagai daya dukung terhadap pencapaian yang ideal dari semua lapisan masyarkat.

2. Koleksi dan pengelola

Perpustakaan menurut namanya dapat diartikan sebagai tempat tersediannya bahan bacaan berupa bahan pustaka seperti buku, majalah, kamus, ensiklopedia, CD, dan karya digital lainnya.

Hadirnya koleksi di perpustakaan setelah mendapat sentuhan dari pengelola perpustakaan yang ditangani secara profesional dengan sistem ilmu tertentu guna memudahkan dalam proses pelayanan mulai dari bagaimana koleksi di adakan, diterima, di olah, sampai pada koleksi siap untuk di pajang pada tempat yang telah di sediakan (rak). Selanjutnya koleksi tersebut akan di artikan bermanfaat apabila telah digunakan oleh pemustaka baik untuk di baca di tempat mapun untuk di bawa pulang (simpan dan pinjam). Segala proses ini terjadi secara berkesinambungan sehingga 
dapat dikatakan sebagai satu sistem yang di terapkan menurut ilmu dan pengetahuan seperti ilmu klasifikasi, katalogisasi dan komputerisasi bahan pustaka.

\section{Program perpustakaan}

Perpustakaan desa akan dirasa memberi manfaat manakala mampu menjadi mitra masyarakat dalam menumbuh kembangkan kemampuan masyarakat seperti menyediakan referensi bagi masyarakat yang bergerak dalam pendidikan, pertanian, perdagangan, seni dan budaya. Untuk itu perpustakaan harus memiliki program yang nyata dan dirasakan manfaatnya oleh masyarakat misalnya perpustakaan membantu masyarakat dalam bidang referensi dalam menumbuh kembangkan minat dan bakat masyarakat dalam bidang seni, olah raga, dan kreatifitas lainnya.

\section{PENUTUP}

Perpustakaan desa menjadi bagian dari program perpustakaan nasional untuk menjawab kebutuhan masyarakat pada lapisan terbawah untuk mengemban amanah mencerdaskan kehidupan bangsa.

Perpustakaan desa/kelurahan berada di bawah naungan pemerintah desa, perpustakaan kabupaten, perpustakaan provinsi, dan perpustakaan nasional yang bergerak dalam bidang informasi baik cetak maupun rekam

Perpustakan desa/kelurahan akan berjalan apabila telah memiliki tempat/gedung, koleksi perpustakaan, pengelola perpustakaan dan didukung oleh program-program perpustakaan yang mampu untuk menjadi sumber solusi bagi setiap kebutuhan masyarakat.

\section{DAFTAR PUSTAKA}

Perpustakaan nasional Ri. 2011. Standar perpustakaan desa/kelurahan SNPoo5:2011 Jakarta: Perpustakaan Nasional RI, 2011

Perpustakaan Nasional Repoblik Indonesia. 2007. Naskah akademik undang-undang perpustakaan (naskah tidak diterbitkan). Jakarta: PNRI

Panduan Trasformasi Perpustakaan yang berkelanjutan. 2019. Jakarta: Perpustakaan Nasional RI

Sutarno NS. 2004, Tanggun Jawab Perpustakaan; jakarta, Bandar buku

Basuki Sulistiyo, 1993, Pengantar ilmu Perpustakaan, Jakarta: Universitas Terbuka 